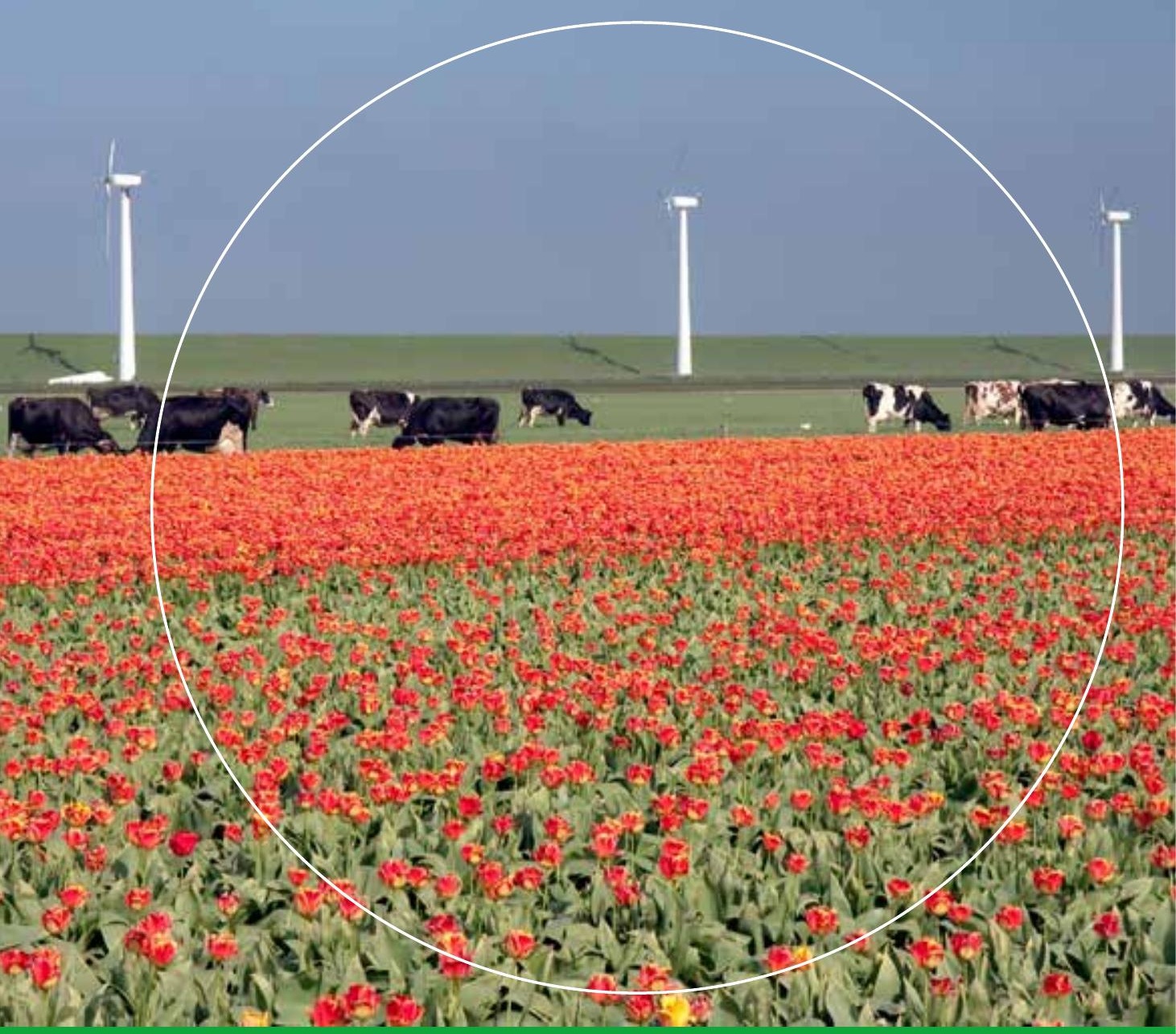

\title{
Food Economic Report 2020 of the Netherlands
}

Summary

H.A.B. van der Meulen 


\section{Food Economic Report 2020 of the Netherlands}

\section{Summary}

H.A.B. van der Meulen

This project was financed by the Dutch Ministry of Agriculture, Nature and Food quality from the public-private partnership 'Economische Informatievoorziening' (projectnummer BO-61-001-002).

Wageningen Economic Research

Wageningen, January 2021

BOOKLET 
Meulen, H.A.B. van der, 2021. Food Economic Report 2020 of the Netherlands; Summary. Wageningen, Wageningen Economic Research, Booklet. 20 pp.; 0 fig.; 5 tab.; 9 ref.

This booklet provides an English summary of the Voedsel-Economisch Bericht 2020 and Duurzaamheid en inkomens in de land-en tuinbouw (www.agrofoodportal.com). It presents a survey of the economic state of Dutch agribusiness. Attention is paid to the development of the agricultural complex, the food industry, the retail chain and the consumption of food. The booklet then proceeds to describe the production structure in the primary agricultural sector, profitability and income formation as well as the environmental performance of the agricultural sector.

This publication can be downloaded at https://doi.org/10.18174/539900 or at www.wur.eu/economic-research (under Wageningen Economic Research publications).

(C) 2021 Wageningen Economic Research

P.O. Box 29703, 2502 LS The Hague, The Netherlands, $\mathrm{T}+31$ (0)70 33583 30, E communications.ssg@wur.nl, http://www.wur.eu/economic-research. Wageningen Economic Research is part of Wageningen University \& Research.

\section{(cc) BY-NC}

This work is licensed under a Creative Commons Attribution-Non Commercial 4.0 International License.

(C) Wageningen Economic Research, part of Stichting Wageningen Research, 2021

The user may reproduce, distribute, and share this work and create derivative works from it. Material by third parties which is used in the work and which are subject to intellectual property rights may not be used without prior permission from the relevant third party. The user must attribute the work by stating the name indicated by the author or licensor, but may not do this in such a way as to create the impression that the author/licensor endorses the use of the work or the work of the user. The user may not use the work for commercial purposes.

Wageningen Economic Research accepts no liability for any damage resulting from the use of the results of this study or the application of the recommendations contained in it.

Wageningen Economic Research is ISO 9001:2015 certified. Wageningen Economic Research Booklet | Project code 2282300260

Cover photo: Shutterstock 


\section{Contents}

$\begin{array}{ll}\text { Preface } & 4\end{array}$

1 The Dutch agricultural sector 5

1.1 The agricultural complex 5

$\begin{array}{lll}1.2 & \text { Food and beverages industry } & 7\end{array}$

$\begin{array}{lll}1.3 & \text { Retail chain and food consumption } & 7\end{array}$

$\begin{array}{lll}1.4 & \text { Trade in agricultural products } & 10\end{array}$

2 The agricultural and horticultural sector $\quad 12$

2.1 Number of holdings 12

2.2 Labour, land, and capital 13

2.3 The sector's income 14

2.4 Environmental performance 16

$\begin{array}{ll}\text { References } & 20\end{array}$ 


\section{Preface}

This booklet provides a summary of two publications, the Food Monitor 2020 (Voedsel-Economisch Bericht) and Sustainability and income development of the primary agricultural sector 2020 (Duurzaamheid en inkomens in de land-en tuinbouw). Both publications have been commissioned by the Ministry of Agriculture, Nature and Food Quality.

The Food Monitor offers a global survey of the Dutch food economy. Attention is paid to the development of the agricultural complex, the food industry, the retail chain and the consumption of food. Based on the Sustainability and income development of the primary agricultural sector report, this booklet then proceeds to describe the production structure in the primary agricultural sector, profitability and income formation as well as the environmental performance of the agricultural sector.

Since its outbreak at the end of December 2019, the Covid-19 pandemic has continued to hold the Netherlands and the rest of the world in its grip. Measures to limit the impact on public health have led to major societal and economic consequences in many sectors, and Dutch agriculture is no exception. However, the consequences of Covid-19 for Dutch agriculture are discussed in limited ways in this publication because some of the figures always lag behind current events.

The Hague, January 2021

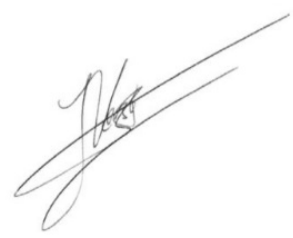

Prof.dr.ir. J.G.A.J. (Jack) van der Vorst

General Director Social Sciences Group (SSG)

Wageningen University \& Research 


\section{The Dutch agricultural sector}

\subsection{The agricultural complex}

The agricultural sector - comprising agriculture, horticulture and fisheries is linked closely to other parts of the economy. For example, agricultural production is virtually impossible without provision of goods and services such as animal feed, fertiliser, energy, machinery, sheds, greenhouses, and veterinary and business services, whilst raw agricultural products require processing in the food industry, trade and distribution before they reach the consumer's table. One can view the entire set of direct and indirect activities surrounding the agricultural sector as one inter-related chain, which we often refer to as the agro (or agricultural) complex.

In this approach the primary sector and the processing industry for food are the main focal point. The size of the agricultural complex is determined by what the primary sector and processing industry need from suppliers and logistics to create the products.

Agro complex delivers $7 \%$ of the GDP (gross domestic product) In 2018 - the most recent year for which figures are available - the added value of the total agro complex amounted to approximately 54 billion euros (Table 1 ). This means the total agro complex contributes $7.0 \%$ to the national gross domestic product (GDP). In 2010, the share in the national total was still $7.4 \%$ and has been fluctuating around the $7.5 \%$ mark in recent years.

In terms of added value, the arable complex is the most significant within the total agro complex with an added value of 26 billion euros. This is due to the large share of imports of coffee, tea, cocoa, and of vegetable oils and fats. Within the agricultural complex based on domestic raw materials, the extensive livestock farming complex has the largest share in added value and employment. 
Employment in the entire agricultural complex has grown during recent years, reaching about 641,000 employment years in 2018 (Table 1), which represents $8.5 \%$ of the national total. Since 2010 , employment in the domestic raw materials-based agro complex has been fairly stable at around 420,000 work years.

Table 1 Gross value added and employment in the Dutch agricultural complex, 2010 and 2018 a)

\begin{tabular}{|c|c|c|c|c|}
\hline & $\begin{array}{l}\text { Added } \\
\text { value } \\
\text { (x billion } \\
\text { euros) }\end{array}$ & $\begin{array}{l}\text { Added } \\
\text { value } \\
\text { ( } x \text { billion } \\
\text { euros) } \\
\end{array}$ & $\begin{array}{l}\text { x 1,000 } \\
\text { annual } \\
\text { labour } \\
\text { units } \\
\end{array}$ & $\begin{array}{l}\text { x 1,000 } \\
\text { annual } \\
\text { labour } \\
\text { units }\end{array}$ \\
\hline & 2010 & 2018 & 2010 & 2018 \\
\hline $\begin{array}{l}\text { Total - domestic, and imported } \\
\text { agricultural raw materials complex }\end{array}$ & 45.5 & 54.1 & 589.5 & 640.9 \\
\hline Share in national total (GDP) & $7.4 \%$ & $7.0 \%$ & $8.5 \%$ & $8.5 \%$ \\
\hline $\begin{array}{l}\text { Totals - imported agricultural raw } \\
\text { materials complex }\end{array}$ & 16.3 & 22.3 & 175.8 & 213.2 \\
\hline Share in national total & $2.6 \%$ & $2.9 \%$ & $2.5 \%$ & $2.8 \%$ \\
\hline $\begin{array}{l}\text { Total - domestic agricultural raw } \\
\text { materials complex }\end{array}$ & 29.2 & 31.8 & 413.7 & 427.7 \\
\hline Share in national total & $4.8 \%$ & $4.1 \%$ & $6.0 \%$ & $5.7 \%$ \\
\hline Primary production & 9.1 & 10.6 & 168.6 & 174.1 \\
\hline Processing & 4.1 & 5.3 & 50.0 & 67.0 \\
\hline Supply & 11.8 & 11.6 & 142.9 & 143.5 \\
\hline Distribution & 4.2 & 4.3 & 52.2 & 43.1 \\
\hline
\end{tabular}

a) The share of added value is calculated as a percentage of GDP and not as a percentage of the national added value.

Source: CBS (Statistics Netherlands) - processed by Wageningen Economic Research.

Export provides a significant contribution to gross value added (GVA) and employment in the agricultural complex An important part of the activities of the agricultural complex is associated with exporting processed and raw agricultural materials. Export contributes about three quarters of GVA and employment over the entire agricultural complex. Dependence on exports varies slightly 
for different parts of the agricultural complex, ranging from $71 \%$ for the arable farming sector to $85 \%$ in the greenhouse horticulture complex.

\subsection{Food and beverages industry}

Measured by sales and employment, the food industry is the largest branch of industry. In 2019, the number of companies in the food industry rose by $5 \%$ to 5,965 . As in 2018 , most of the growth has taken place in the dairy sector and is for the account of dairy farmers who have invested in processing their own milk, yoghurt and (to a lesser extent) cheese. Several industrial sectors are included in these figures, from fruit and vegetable processing to abattoirs, meat products industry, bakeries, and baked goods. The tobacco industries are not included. The beverage industry included 855 companies in 2019.

\subsection{Retail chain and food consumption}

In 2019, the total foodstuff turnover through all sales channels in the Netherlands reached almost 65 billion euros; an increase of about $5 \%$ relative to 2018 (Table 2). That sum involves retail sales (supermarkets and other retail outlets, e.g. markets and specialised businesses), and the food service sector (hotels and restaurants, catering, leisure and sales points 'on the move').

The revenue from food and drinks in retail in 2019 represents around 44 billion euros. Of all food turnover in the retail trade, 34.3 billion euros is generated by supermarkets, making them the most important sales channel for food and drink. The increased turnover was partly caused by the VAT increase from $6 \%$ to $9 \%$ at the beginning of 2019 , which made all foodstuffs $3 \%$ more expensive.

The food service sector accounts for almost a third of all sales. The shares of retail and food service are relatively stable. Together cafés, hotels and restaurants; the recreational sector; catering; and roadside sales points saw 21 billion euros in sales, an increase of 1 billion euros 
compared with 2018. Table 2 lists food and drink sales per type of sales channel. The boundaries between the types of sales channels have become increasingly blurred over the years. For instance, retailers in the food sector have greater opportunities to develop food service activities in their stores, and catering outlets are being set up in areas of stores. Supermarkets are selling more and more meals, and in some restaurants you can buy products. Sometimes the initiatives take things a step further by combining shops, restaurants and market stalls in 'market halls' or 'food halls'.

Table 2 Food and drink turnover in the Netherlands, 2018 and 2019, in billions of euros

\begin{tabular}{lrr} 
& 2018 & $\mathbf{2 0 1 9}$ \\
Supermarkets & $\mathbf{3 2 . 7}$ & $\mathbf{3 4 . 3}$ \\
\hline Small retail and online retail (incl. temporary retail locations) a) & $\mathbf{9 . 0}$ & $\mathbf{9 . 3}$ \\
\hline Food service, b) of which & $\mathbf{2 0 . 1}$ & $\mathbf{2 1 . 0}$ \\
\hline Hospitality & 12.7 & 13.3 \\
\hline Sport and recreation c) & 1.4 & 1.4 \\
\hline Catering & 3.3 & 3.4 \\
\hline Roadside d) & 2.7 & 2.8 \\
\hline
\end{tabular}

a) Online delivery service by supermarkets is, whenever possible, included in online retail.

b) Including online delivery service of meals.

c) Expenditures in sports facilities, recreation parks, amusement parks, etc.

d) Expenditures in petrol stations and catering in retail and (public) transport.

Source: Foodstep (food service), CBS (supermarkets), FSIN (other). Editing: Wageningen Economic Research.

The large supermarket chains such as Ahold Delhaize (Albert Heijn), Jumbo, Lidl, and Aldi buy independently, while the smaller chains are members of the wholesale purchasing cooperative Superunie. Superunie is a collective purchasing association encompassing mainly (but not exclusively) regional supermarket chains, and represents a $26 \%$ share of the supermarket purchasing market. Ahold/Delhaize tops the league for turnover and market share in the Netherlands. In 2019, Ahold/Delhaize realised almost 15 billion euros of turnover, Jumbo comes in a safe second, with a turnover of almost 9 billion euros. Together, Albert Heijn/AH ventures and Jumbo control $56 \%$ of the market. Lidl follows in third place with a market share of almost $11 \%$ in 2018. 
Increased household expenditure on food

In 2019, total consumer expenditure on goods and services of Dutch households was approximately 356 billion euros. More than 45 billion euros was spent on food and drinks (Table 3). This concerns consumer spending in the retail sector (including supermarkets, speciality shops, open-air markets, Internet shops and non-food shops) and direct sales. Expenditure on food and drinks amounted to $12.8 \%$ of total consumer spending on goods and services in 2019. This percentage has been stable in recent years. Expenditure on food in the hotel and catering industry and recreation is included in the expenditure on services and is not reflected in the share of food and drinks in consumer expenditure.

Table 3 Household consumer expenditure (a) (billions of euros) (b) 2015-2019

\begin{tabular}{lrrrrr} 
& 2015 & 2016 & 2017 & 2018 & 2019 d) \\
$\begin{array}{l}\text { Total consumer expenditure } \\
\text { on goods and services }\end{array}$ & 301 & 315 & 327 & 342 & 356 \\
\hline $\begin{array}{l}\text { Foods and Beverages c) } \\
\text { Share (\%) foodstuffs and }\end{array}$ & 40 & 41 & 42 & 44 & 45 \\
\hline drinks & 13.0 & 12.9 & 13.0 & 12.7 & 12.8 \\
\hline
\end{tabular}

a) Refers to household expenditure on consumables including non-profit organisations serving households.

b) At actual prices.

c) Relates to consumer spending via trade or direct spending. Spending on hotels and catering is not included. This falls under expenditure on services; d) Provisional data.

Source: CBS - processed by Wageningen Economic Research.

Consumption of foodstuffs from sustainable and organic production continuous to grow

Total consumer spending on sustainable food, products bearing a certification logo with independent control, amounted to 7.7 billion euros in 2019: an increase of $18 \%$ when compared with 2018. The share of sustainable food within the total food spending was $14 \%$ in 2019 . Across all product groups, consumers have more often chosen to include an organic product as part of their basic groceries in recent years. The turnover of products with the 'On The Way to PlanetProof' certification increased five-fold in 2019 relative to 2018 . This certification 
programme entails a balanced consideration between various different sustainability themes: soil, landscape and biodiversity, water, energy, production and consumption, climate, animal health and welfare. The certification was introduced in 2017 and can now be found on products such as potatoes, onions, vegetables and fruit, herbs, dairy products, eggs and drinks. Products which are produced under other sustainability certification systems, such as Beter Leven (quality label for animal welfare), UTZ Certified, Fair Trade, Aquaculture Stewardship Council (ASC, a quality label for farmed fish) also account for an increasing proportion of the range (Logatcheva, 2020).

\subsection{Trade in agricultural products}

Agricultural goods exports reach new high despite corona

Dutch agricultural exports are estimated at 95.6 billion euros for 2020, which is $1.0 \%$ higher than in 2019 (94.6 billion euros). Despite the corona crisis, the Netherlands is likely to set a new agricultural export record in 2020. However, due to sharply lower exports in November and December 2020 - the effect of a second wave in the corona pandemic the figure for 2020 may be slightly lower than in 2019. The value of agricultural imports is estimated at 67.1 billion euros in $2020(+4.5 \%)$. The trade surplus, the balance of exports and imports, is estimated at 28.5 billion euros for 2020 , less than in the previous three years. In 2019, the surplus was 30.5 billion euros (Jukema et al., 2021).

Export growth can be fully attributed to growth in re-exports Dutch agricultural exports consist of re-exports (unprocessed or semiprocessed imports that pass through the Netherlands to a third country) and exports of Dutch products. In 2020, exports of Dutch products are estimated at 68.3 billion euros and re-exports at 27.3 billion euros. This amounts to a decline of $0.6 \%$ of exports of Dutch products relative to 2019 and a growth of $5.1 \%$ in re-exports. The entire growth in total agricultural exports is therefore due to the growth in re-exports of agricultural goods. The share of re-exports in total agricultural exports has been growing steadily for years, from $27.1 \%$ in 2016 to $28.6 \%$ in 2020 (Jukema et al., 2021). 
EU most important trade partner

In 2020, about $73 \%$ of Dutch agricultural exports went to EU countries (including the United Kingdom). Germany, Belgium, the UK, and France accounted for approximately $54 \%$ of the exports. The most important export products are flowers and plants, meat, dairy and eggs, vegetables and fruit (Jukema et al., 2021). 


\section{The agricultural and horticultural sector}

\subsection{Number of holdings}

The number of agricultural and horticultural companies fell to 53,230 in 2019, a decrease of $1.3 \%$ (Table 4). That is less than the long-term average of $2 \%$ to $3 \%$ per year. In 2016 , due to changes in the registration of the agricultural and horticultural companies, the number of farms saw a sharp one-time decline (13\%). The most important change is that companies not listed in the trade register (Chamber of Commerce) with agrarian activity, are no longer included in the agricultural census.

Table 4 Developments in the numbers of holdings and employees, and total area of farmland from 2000 onwards

\begin{tabular}{lrrrrr} 
& 2000 & 2005 & 2010 & 2018 & 2019 \\
$\begin{array}{l}\text { Number of agricultural and } \\
\text { horticultural farms (x 1,000) }\end{array}$ & 97,389 & 81,750 & 72.324 & 53,910 & 53,233 \\
\hline Number of workers (x 1,000) a) & 212.1 & 174.7 & 169.6 & 153.4 & 156.3 \\
\hline Area of farmland (x 1.000 ha) & $1,975.5$ & $1,937.7$ & $1,872.3$ & $1,822.4$ & $1,816.3$ \\
\hline
\end{tabular}

a) Annual working unit.

Source: CBS (Statistics Netherlands) agricultural census, processed by Wageningen Economic Research.

In horticulture, the number of farms in greenhouse horticulture increased in 2019 with almost 3\%. As a result, the downward trend appears to be slowing. In recent years, the average farm size has increased, partly as a result of a number of years with good economic results. The number of dairy farms fell in 2018 en 2019 by almost $9 \%$, mainly due to measures to reduce phosphate production in the dairy sector. The number of intensive livestock farms decreased by $2.9 \%$ in 2019. That is slightly less than the average long-term decline of $4 \%$ per 
year. In the coming years, the number of intensive pig farms will fall more rapidly through a purchase scheme aimed at reducing odour nuisance in densely populated areas.

After a period (2009-2013) in which relatively many farms and horticultural operations (approximately 100 per year) were declared bankrupt, the number of bankruptcies fell sharply to only 20 per year in the period 2017-2019. In the first half of 2020, the number of bankruptcies also remained low (seven). The vast majority of bankruptcies (85\% in the period 2000-2019) were in horticulture, especially greenhouse horticulture.

\subsection{Labour, land, and capital}

The total number of persons regularly employed in the primary agricultural and horticultural sector increased again by almost 3,000 to just over $156,000(+1.9 \%)$ in 2019 (Table 4$)$. This is the result of a small decrease in the number of farms and growing operations and an increase in the workforce per farm or growing operation. This means a break in the virtually continuous decline in the number of workers by an average of $2 \%$ between 2000-2017.

Around $55 \%$ of the labour input are part of the family In 2019 , more than 85,000 of the regularly employed (permanent) labour force are family members (farmers, spouses and other coworking family members), i.e. $54 \%$. This is the same percentage as in 2018 . In 2019, the number of non-family workers (also described as staff) increased by more than $4 \%$ to 71,200 under the effects of economic growth. These figures only partly include flexible labour (temporary workers from agencies and personnel with short-term contracts). The regular employees usually have full-time jobs all year round, while flexible employees, particularly in the open-field horticulture sector, only come in for peak periods. This makes it difficult to determine, or even estimate, the number of flexible workers. In the harvest/peak periods, although large numbers of people may be at work, this is only for short/very short periods. 
Use of agricultural area

Farms and nurseries had an agricultural area of almost 1.82 million ha in use in 2019, slightly less than in 2018 (Table 4). Over a somewhat longer period (2000-2018), the agricultural area in use fell by an average of $0.4 \%$ per year. Of the total area of cultivated land, $54 \%$ is now in use as grassland (permanent, temporary and natural), $11 \%$ for green fodder crops, $29 \%$ for other arable production, $5 \%$ for open-field horticulture and $0.5 \%$ for greenhouse horticulture.

Balance sheet value of agriculture and horticulture 3.5 million euros in 2019

The balance sheet value of the farms and horticultural businesses at the end of the financial year was on average more than 3.5 million euros per farm in 2019. Compared to 2018, this is almost the same. Long-term debts decreased slightly, to an average of 800,000 euros per farm.

Since the beginning of this decade (2010), the average book value of agricultural and horticultural holdings increased by around 1.0 million euros, mainly due to increased average farm size, higher farmland prices and introduction of phosphate rights in 2018 in the dairy sector. In the same period the solvency rate (part that is financed with in-house capital) increased from $67 \%$ to $74 \%$. By the end of 2019 , the land represented $52 \%$ of the total balance-sheet value, compared to $46 \%$ in 2010 .

\subsection{The sector's income}

The average farm income for agricultural and horticultural businesses in 2020 is estimated at around 54,000 euros per unpaid annual work unit (AWU). Despite corona support measures from the government, this amounts to a decline of almost 20,000 euros compared to the good agricultural year 2019. The income is also lower than the multiannual average of 59,000 euros over the period 2015-2019. Average revenues per farm or growing operation for the total agriculture and horticulture sectors are expected to fall by $2 \%$, mainly due to a drop in demand as a result of the corona pandemic. Expenditure and depreciation are expected to increase by an average of $3 \%$ in 2020 , mainly due to growth in the size of farms or growing operations. Each year the 
agriculture and horticulture sector sees significant differences in income, both within a given sector and among the various sectors.

After reaching a historically high level in $2019,{ }^{1}$ the average net income of pig farmers is expected to become negative in 2020. This is caused by higher costs due to the increased average size of farms, as well as lower prices for piglets and fattening pigs due to the corona pandemic and the outbreak of African swine fever in Germany. In combination with a ban on exports to important third countries such as China, this puts a strong downward pressure on the European pig price. Arable farmers are struggling with lower potato prices, an important source of income in this subsector, causing their incomes to drop slightly to around 40,000 euros. Dairy farmers are also seeing their income fall - to 43,000 euros - due to lower milk prices and higher feed costs. Broiler farmers are seeing a decline in their turnover due to the temporary closure of food service companies at home and abroad. As a result, their income will drop significantly in 2020 to 44,000 euros on average. In greenhouse horticulture, the incomes of vegetable growers and cut flower growers are falling. In the greenhouse vegetable sector, costs are rising faster than revenues. The turnover of cut flowers has remained lower after the announcement of lockdown measures in various countries this spring. The income of potted plant and bedding plant growers is estimated to be higher than in 2019 , with an average income of 180,000 euros.

Although revenues are declining due to a drop in demand from corona measures, costs have fallen even more, especially for starting materials (seeds, cuttings, etc.) and energy. Tree growers, fruit growers, field vegetable growers and dairy goat farmers are also expected to see their incomes increase in 2020 due to better prices for their products.

While in 2017 and 2019 the average agricultural holding received a market-based payment for use of its own labour and equity, in 2020 profitability will be 98 euros of income per 100 euros of costs.

1 Income $=$ income from business per unpaid annual work unit. 


\subsection{Environmental performance}

The environmental impact of the primary agriculture and horticulture sector is visible and measurable through different environmental indicators. There is wide ranging variation between developments connected with each environmental issue.

The agricultural sector is with a share of approximately $85 \%$ the main source for the emission of ammonia. The ammonia emissions from stables and in the use and storage of animal manure make up the lion's share of ammonia emissions. Since 2010, ammonia emissions are virtually stable at a level of around 110-115 million $\mathrm{kg}$ (Table 5). For the 2020-2030 period, a 13\% decrease in ammonia emissions from all sources has been agreed in the EU when compared to 2005 (134 million $\mathrm{kg}$ ). This objective has already been achieved. However, nitrogen deposition, partly as a result of ammonia emissions, is still too high in the Netherlands to achieve biodiversity targets. Although the Dutch agricultural sector has more than halved its emissions since 1990, ammonia emissions per hectare of agricultural land are still $60 \mathrm{~kg}$, the highest in the EU (CLO). On 13 November 2019, the government announced two measures for agriculture that should lead to a decrease in nitrogen deposition in the short term. The first measure concerned ammonia reduction through a change in feed composition. Animal feed often contains more protein than an animal needs, leading to more ammonia in the urine and manure. Ultimately this feed measure was not introduced because the reduction in nitrogen resulting from the measure was considered too small (LNV, 2020).

The second measure involved cutting the total number of livestock through a compensated reorganisation scheme for pig farmers (LNV, 2019).

Pesticide sales have been fluctuating at around 10 million $\mathrm{kg}$ of active ingredients per year. In 2018, sales were 9.3 million $\mathrm{kg}$, which is more than $11 \%$ lower than in 2017 . More than $45 \%$ of the products are fungicides, about $30 \%$ are herbicides (weed control agents, including glyphosate) and about $20 \%$ are other types of products, especially soil disinfectants and mineral oils. Fluctuations in usage are closely related 
to the weather. The summer of 2018 was very sunny and dry. Warm and dry summers lead to lower use of pesticides, while cold and wet summers lead to higher use. Around $98 \%$ of total pesticide sales were for use in agriculture and horticulture. Retail users or public park and garden managers used the remainder. These are often herbicides.

In addition to use in absolute quantities, the environmental impact of the products used per $\mathrm{kg}$ of active ingredient is a significant indicator. The environmental impact on arable farming has almost been halved in the period 2008-2018 due to the ongoing remediation of relatively harmful substances.

Table 5 Development of the environmental impact of agriculture and horticulture, 2000-2018

\begin{tabular}{lrrrrr} 
& 2000 & 2005 & 2010 & 2017 & 2018 \\
$\begin{array}{l}\text { Use of crop protection } \\
\text { agents (in million kg of } \\
\text { active substance) a) }\end{array}$ & - & - & 9.559 & 10.573 & 9.385 \\
\hline $\begin{array}{l}\text { Greenhouse gas emissions } \\
\text { (in billion } \mathrm{CO}_{2} \text { equivalents, }\end{array}$ & 28.5 & 26.1 & 28.8 & 27.4 & 26.5 \\
\begin{tabular}{l} 
IPPC) \\
\hline $\begin{array}{l}\text { Surplus of nitrogen (N, kg } \\
\text { per hectare) }\end{array}$
\end{tabular} & 183 & 142 & 114 & 118 & 132 \\
\hline $\begin{array}{l}\text { Surplus of phosphates ( } \mathrm{P}_{2} \mathrm{O}_{5}, \\
\text { kg per hectare) }\end{array}$ & 52 & 36 & 27 & 6 & 18 \\
\hline $\begin{array}{l}\text { Ammonia emissions (in } \\
\text { million kg) }\end{array}$ & 156 & 134 & 116 & 113 & 111 \\
\hline
\end{tabular}

a) In previous years the figures were based on sales data published by Nefyto. These figures are currently published by Statistics Netherlands based on data that Stichting Fytostat (Fytostat Foundation) collects from all companies affiliated with Nefyto that market plant protection products in the Netherlands. The Dutch Food and Consumer Product Safety Authority (NVWA) supplements these data with approximately $5 \%$ of total sales that are not marketed by Nefyto members (source: CBS). The sales data based on the CBS figures are therefore higher than those previously based on the Nefyto figures, and are available from 2010.

Sources: CBS - RIVM (Dutch National Institute for Public Health and the Environment)/CBS, Milieucompendium (Environment Compendium), various years. 
Greenhouse gas emissions have fallen sharply since 1990 but they have remained fairly stable in recent years. In 2018, emissions were approximately 26.5 megatonnes $\mathrm{CO}_{2}$ eq, slightly lower than in 2017 and more than 20\% lower than in 1990 (Table 5).

Greenhouse horticulture is subject to the Long-Term Energy Transition Agreement for Greenhouse Horticulture 2014-2020 (Ministry of Economic Affairs, 2014). The original $\mathrm{CO}_{2}$ target (6.2 megatonnes in 2020) was tightened to 4.6 megatonnes in 2017 due to shrinking glass acreage and reduced electricity sales. In 2019, $\mathrm{CO}_{2}$ emissions increased to 5.9 megatonnes, which is 1.3 megatonnes above the target for 2020 . In 2019, $\mathrm{CO}_{2}$ emissions increased mainly due to an increase in acreage. $\mathrm{CO}_{2}$ emissions also increased because more electricity was sold and less non-sustainable heat was purchased. The growth of renewable energy and electricity purchasing partly offset the increased $\mathrm{CO}_{2}$ emissions. The share of renewable energy in total energy consumption grew strongly in 2019 to $9.4 \%$. Geothermal energy was the most important sustainable source (Van der Velden and Smit, 2020).

The share of agriculture and horticulture in total greenhouse gas emissions in the Netherlands is around $17 \%$. The Climate and Energy Outlook 2020 (PBL, 2020) predicts that total greenhouse gas emissions from the agricultural sector in 2030 will amount to 24.5 megatonnes $\mathrm{CO}_{2}$ eq (within a bandwidth of 21.9 to 25.6 megatonnes $\mathrm{CO}_{2} \mathrm{eq}$ ). According to the Outlook, that is $25 \%$ lower than in 1990.

The Climate Agreement sets an additional target for 2030 for the agricultural and land-use sectors. This concerns an additional reduction of 3.5 megatonnes of greenhouse gas emissions on top of existing policy. This means that by 2030 , annual emissions from agriculture and land use must not exceed 27.6 megatonnes $\mathrm{CO}_{2}$ eq (PBL, 2018).

There has been a strong reduction in surpluses of nitrogen and phosphate per hectare as a consequence of the export of manure, a reduction in the use of artificial fertiliser and lower phosphate levels in feed and thus in manure (Table 5). However, the figures for 2018 indicate an increase in the surplus per hectare for both nitrogen and phosphate. For phosphate, this is a consequence of the extreme drought 
and the corresponding drop in crop yields in arable farming. As a result, the extraction of phosphate from the soil by crops was considerably lower. More phosphate was supplied via feed in dairy farming because more feed had to be purchased due to poor crop growth. Drought has also played an important role in the higher nitrogen surpluses.

The total production of phosphate and nitrogen is subject to a fixed ceiling; the excretion of nutrients must not exceed 173 million $\mathrm{kg}$ of phosphate and 504 million $\mathrm{kg}$ of nitrogen (including gaseous losses) in any one year. In 2015 and 2016 the limit for phosphate was exceeded, due mainly to higher phosphate production in dairy farming. In 2017, the amount of phosphate in animal manure was again lower than the limit set by the EU, thanks to the measures taken to reduce phosphate production in dairy farming. In 2018 and 2019, phosphate production fell further to 162 respectively 156 million $\mathrm{kg}$, which was mainly due to a decline in dairy farming.

In 2017, nitrogen production exceeded the limit for the first time, at 512 million $\mathrm{kg}$. In 2018, nitrogen production from Dutch livestock once again fell to 504 million $\mathrm{kg}$, i.e. to the exact level of the set limit. In 2019 as well, production was 490 million $\mathrm{kg}$ below the ceiling. This reduction is attributable to grazing livestock, due to a fall in the number of dairy and veal cows and young cattle. 


\section{References}

CLO. Compendium voor de Leefomgeving. Via https://www.clo.nl/

Jukema, G.D., P. Ramaekers en P. Berkhout (Red.), 2021. De Nederlandse agrarische sector in internationaal verband - editie 2021. Wageningen/Heerlen/Den Haag, Wageningen Economic Research en Centraal Bureau voor de Statistiek, Rapport 2021-001.

Logatcheva, K. (2020). Monitor Duurzaam Voedsel 2019. Wageningen, Wageningen Economic Research, Rapport 2020-072.

LNV (Ministerie van Landbouw, Natuur en Voedselkwaliteit) (2019): Maatregelenpakket voor de stikstofproblematiek in de woningbouw - en infrastructuursector en voor de PFASproblematiek.

LNV (2020). Brief aan de Voorzitter van de Tweede Kamer der Staten Generaal. "Bijstelling pakket aanpak stikstofproblematiek". D.d. 19 augustus 2020.

Ministery of Economic Affairs (2014). Meerjarenafspraak Energietransitie Glastuinbouw 2014-2020

PBL (Planbureau voor de Leefomgeving) (2018). Uitgangspuntennotitie voor de onderhandelingen aan de sectortafel Landbouw en Landgebruik.

PBL (2020). Klimaat en energieverkenning 2020.

https://www.pbl.nl/publicaties/klimaat-en-energieverkenning-2020

Van der Velden, N. en P. Smit (2020). Energiemonitor van de Nederlandse glastuinbouw 2019, Rapport 2020-109. Wageningen Economic Research. 
The mission of Wageningen University \& Research is "To explore the potential of nature to improve the quality of life". Under the banner Wageningen University \& Research, Wageningen University and the specialised research institutes of the Wageningen Research Foundation have joined forces in contributing to finding solutions to important questions in the domain of healthy food and living environment. With its roughly 30 branches, 6,500 employees (5,500 fte) and 12,500 students, Wageningen University \& Research is one of the leading organisations in its domain. The unique Wageningen approach lies in its integrated approach to issues and the collaboration between different disciplines.

Wageningen Economic Research

P.O. Box 29703

2502 LS Den Haag

The Netherlands

E communications.ssg@wur.nl

www.wur.eu/economic-research

\section{BOOKLET}

